\title{
The Relationship between CSR and Banks' Financial Performance: Evidence from Turkey
}

\author{
Kurumsal Sosyal Sorumluluk ve Bankaların Finansal \\ Performansları Arasındaki İlişki: Türkiye’den Kanıtlar
}

\author{
Dilvin Taşkın, Yasar University, Türkiye, dilvin.taskin@yasar.edu.tr
}

\begin{abstract}
The aim of this paper is to analyze the bidirectional relationship between CSR practices of Turkish banks and their financial performance which is proxied by ROE, ROA and NIM for the year 2013. Content analysis is used to analyze the degree of CSR level based on a CSR index calculation and the link between performance and CSR level is investigated. The results show that ROA and ROE have no explanatory power in explaining CSR, whereas there is a bidirectional relationship between CSR and NIMs. The results point to an intuition that the banks are likely to charge the costs of CSR practices from their customers.
\end{abstract}

Keywords: Banking, Corporate Social Responsibility, Financial Performance

Öz: Bu çalışmanın amacı Türkiye'de faaliyet gösteren bankaların 2013 yılındaki Kurumsal Sosyal Sorumluluk (KSS)uygulamalarının, aktif karlılı̆̆l, özkaynak karlılı̆̆ ve net faiz marjıdeğişkenleri ile ölçüldüğ̈̈ banka performansı arasındaki olası çift yönlü ilişkiyi incelemektir.KSS düzeyi içerik analizi yöntemi kullanılarak bir KSS endeksine bağlanmış, performans ve KSS düzeyi bağlantısı ilişkilendirilmiştir. Çalışmanın sonuçlarına göre aktif karlılı̆̆ ve özkaynak karlıllı̆ııın KSS faaliyetleri üzerinde herhangi bir etkisi olmamakla beraber, KSS ve net faiz marjları arasında çift yönlü ilişkinin varlı̆̆ tespit edilmiştir. Bu durum ise bize bankaların KSS faaliyetlerinden doğan maliyetleri müşterilerine yansittı̆g fikrini akla getirmektedir.

Anahtar Kelimeler: Bankacılı, Kurumsal Sosyal Sorumluluk, Finansal Performans

\section{Introduction}

The Turkish banking industry makes up approximately $80 \%$ of the whole financial system. Thus, any development in this sector is crucial for every actor in the society. Following the developments in the world, the financial system in Turkey started to liberalize with the beginning of 1980s. The interest rate ceilings were removed, the convertibility of the Turkish Lira was established. With the liberalization efforts, the rules of the game have changed, but the problem was the policies were introduced before any proper regulation was imposed. Thus, banking system ended up with two severe crises in 1994 and 2001.

In 2001 crisis half of the total assets of the total banking system melt down due to depreciation in Turkish Lira and some of the banks were taken over by Savings Deposit and Insurance Fund. In order to provide financial stability a stand-by agreement with IMF was signed and also a "Transition Program for Strengthening the Turkish Economy" was put into action. With the recovery of the economy, the banking system also improved. The profitability and the capital adequacy of the total banking system increased to levels that are considerably higher than the average European bank.

After 2002 the face of the banking system changed radically. Before the crisis, the banks enjoyed the high interest rates from the treasury bills, by channeling the funds from their depositors. In the aftermath of the crisis, due to the rapid decrease in interest rates banks started to perform their traditional banking activities and started to give loans to individuals and firms. Many 
banks either merged or acquired, lots of foreign banks entered to the market and there has been a brisk consolidation in the system. Table 1 provides a general overview about the banking system in the aftermath of the crisis. These changes started to increase the competition in the system and also with the recovery and increased profits, the banks started to increase their corporate social responsibility activities. Especially, the biggest banks publish sustainability reports that are in line with the global standards. Most of the banks, especially private national banks engage in many CSR activities that are related to planting forests, increasing energy efficiency, education and arts.

Table 1. General Overview of Turkish Banking System

\begin{tabular}{|c|c|c|c|c|c|c|}
\hline Year & $\mathrm{C} 3$ & C5 & $\begin{array}{l}\text { Share of } \\
\text { Foreign } \\
\text { Banks } \\
\end{array}$ & $\begin{array}{l}\text { Total Number } \\
\text { of } \\
\text { Commercial } \\
\text { Banks }\end{array}$ & \begin{tabular}{|l} 
Number of \\
Com. Bank \\
Branches
\end{tabular} & $\begin{array}{l}\text { Number of } \\
\text { Personel }\end{array}$ \\
\hline 2003 & 0,448 & 0,643 & 0,030 & 36 & \begin{tabular}{|l|}
5949 \\
\end{tabular} & 118607 \\
\hline 2004 & 0,442 & 0,634 & 0,032 & 35 & 6088 & 122630 \\
\hline 2005 & 0,472 & 0,640 & 0,053 & 34 & 6228 & 127857 \\
\hline 2006 & 0,435 & 0,623 & 0,125 & 33 & 6804 & 138570 \\
\hline 2007 & 0,423 & 0,641 & 0,150 & 33 & 7570 & 153212 \\
\hline 2008 & 0,426 & 0,639 & 0,153 & 32 & 8741 & 166325 \\
\hline 2009 & 0,452 & 0,663 & 0,125 & 32 & 8983 & 167063 \\
\hline 2010 & 0,444 & 0,660 & 0,132 & 32 & 9423 & 173133 \\
\hline 2011 & 0,420 & 0,636 & 0,139 & 31 & 9792 & 176576 \\
\hline 2012 & 0,401 & 0,624 & 0,140 & 32 & 10192 & 181197 \\
\hline 2013 & 0,393 & 0,606 & 0,153 & 32 & 10981 & 192219 \\
\hline
\end{tabular}

C3 and C5 represent the share of the biggest 3 and 5-banks, respectively. The data is collected

from the web site of TBAT, The Banks Association of Turkey.

The CSR disclosure in Turkey is shaped by the "Corporate Governance Principles" (Nuhoglu and Wan, 2012: 96) which are established by Capital Markets Board of Turkey in 2003 and later revised in 2005 and 2011. These principles are based on OECD corporate governance criteria and they stress the importance of protecting shareholders' and stakeholders' rights. They also focus on social and environmental awareness. The companies which are listed in the Borsa Istanbul should explain their compliance with those principles and in the case of non-compliance they should disclose the reasons for it. Ararat (2008) also note that multinational companies are concerned with the CSR, only if the society asks for it. If that's the case, the multinationals note the CSR activities as a profit maximizing differentiator. The latest events in Turkey (Gezi protests and other environmental protests) show that the society calls for higher social standards especially to protect the environment. This is idea also links the social and financial performance.

Despite various attempts to define corporate social responsibility (CSR), there is no clear definition of CSR yet (Turker, 2009). Some researchers define CSR as "strategies for dealing with stakeholder demands" (Ullmann, 1985: 552). By this definition, CSR is directly in line with corporate governance. But, this paper adopts a more comprehensive definition, such as the one made by Carroll (1999). Carroll (1999) defines the CSR in two dimensions; economic and noneconomic. Economic components represent the activities that the company is doing for itself, noneconomic components stand for the activities that the company serves for the society.

The paper proceeds with the aim of analyzing the impact of CSR practices on the financial performance of Turkish banks; namely return on assets (ROA), return on equity (ROE) and net interest margins (NIM). Conversely the impact of financial performance on the CSR activities is 
Taşkın, D. / Journal of Yasar University, 2015, Special Issue, 21-30

also analyzed by controlling the size. In order to have a prompt measure of CSR, a score is calculated for each bank based on their disclosures and the items in GRI index. The next section presents a brief literature, Section 3 will present the data and methodology, Section 4 will display the empirical results of the study and finally Section 5 will conclude.

\section{Literature Review}

Since, the aim of the firm is mentioned as maximizing shareholders' wealth, there are many papers linking the CSR practices to financial performance measures. But still, the literature is inconclusive about the CSR and financial performance relationship. In the traditional view of the corporation, the responsibility of the firm is limited to serve the needs of shareholders. As Friedman states (1962: 163) "The responsibility of business is to increase profits". Despite the harsh regret of Friedman, many papers still reject his view. McWilliams and Siegel (2001) remarked that based on a supply and demand theory of the firm, the firms produce at a profit-maximizing level, including the production of social performance. It is also believed that good management will be performing well in every aspects of business, even in social performance (Waddock and Graves, 1997). Preston and O'Bannon (1997) mention that a firm with a superior financial performance has slack resources which can be directed to social performance.

With the increase in CSR practices, the initial papers started to address the link between the pollution control disclosure and several measures of performance (i.e. Bragdon and Marlin, 1972; Belkaoui, 1976).

Some papers point to a positive relationship between social and financial performance. Frooman (1997) analyzed the market reaction for the firms that are found as socially irresponsible or illegal were negative. The event studies showed that the investors sold the shares of these firms when a bad new about the irresponsible behavior or legal misconduct of a firm is heard. Stanwick and Stanwick (1998) using the Fortune Survey of Corporate Reputation as a proxy for CSR practices investigated its link with financial performance variables like return on sales and size for the years 1987 and 1992. The results revealed a positive relationship between CSR and financial performance. This finding was also supported by Preston and O'Bannon (1997) who examined three dimensions of Fortune Reputation Survey on 67 large corporations in US for the period 19821992. They also indicate a positive association between the aggregate 3 dimensions on CSR and return on assets, return on equity and return on investments.

As the earlier studies about CSR focus on only one dimension related to CSR, more recent studies consider multidimensional features of CSR practices using CSR indices like KLD index, CSID (Canadian Social Investment Database). These indices provide means to measure CSR level for each firm by considering several dimensions and assigning a score pertaining the firms' success in each dimension.

Despite the vast amount of papers focusing on the impact of CSR on financial performance, several researchers assert that it's the financial performance that affects the CSR activities of a company. Ullman (1985) in his stakeholder model, economic performance is posited as an independent variable effecting CSR. McGuire et al. (1988) also concluded that the firms with higher performance are more likely to afford social responsibility projects. Zengin Karaibrahimoglu (2010) also inferred a similar view with Ullman and proved that in times of global financial turmoil there has been a decrease in the CSR projects on a randomly selected 100, Fortune-500 companies. 
Taşkın, D. / Journal of Yasar University, 2015, Special Issue, 21-30

\section{Data and Methodology}

The analysis covers 11 banks which are private national commercial banks operating in Turkey in $2013^{1}$. The sample banks constitute the $53.1 \%$ of the total assets in the banking system, whereas the public banks make up the $30.9 \%$ of total assets and foreign banks represent $16.0 \%$. The public banks serve as the bodies that both channel funds between suppliers and demanders and funds and also they are the means to serve public needs. So their CSR practices are considered more obligatory than voluntary. The foreign commercial banks represent very small percentages in total market share and most of them have very few branches. Thus, only very small number of foreign banks were found to exercise CSR practices, hence they were also ignored from the analysis.

In order to identify the corporate social responsibility practices of the private commercial banks in Turkey, their financial statements and footnotes, annual reports, corporate social responsibility reports and sustainability reports have been investigated for the year 2013. Of the available scales for the measurement of CSR, Global Reporting Initiative's (GRI) sustainability report guidelines is adopted as in Nuhoglu and Wan, 2012. The study makes a content analysis based on the guidelines that are mentioned in GRI.

The GRI focuses on Triple Bottom Line concepts for measuring the degree of CSR, namely, economic impacts, environmental impacts and social impacts. The social impacts are further traced into four sub-dimensions: labor practice and decent work, human rights, society and product responsibility. If the bank discloses all the required information about a dimension, it is given a score of 10; thus a bank that is fulfilling disclosure requirements about each dimension it will get a score of 60 in total. Table 2 summarizes the sub-dimensions of CSR practices that were traced in the content analysis.

Table 2. Dimensions of CSR Practices used in Content Analysis

\begin{tabular}{|c|c|c|c|}
\hline \multicolumn{2}{|c|}{ CSR Dimensions } & Score & Content \\
\hline \multicolumn{2}{|c|}{ Economic Information } & 10 & $\begin{array}{l}\text { Economic Performance, Market Presence, Indirect Economic } \\
\text { Impacts }\end{array}$ \\
\hline \multicolumn{2}{|c|}{$\begin{array}{l}\text { Environmental } \\
\text { Information }\end{array}$} & 10 & $\begin{array}{l}\text { Material, Energy, Water, Biodiversity, Emissions effluents } \\
\text { waste, Products\&Services, Compliance, Transport; Overall }\end{array}$ \\
\hline \multirow{3}{*}{ : } & $\begin{array}{l}\text { Labor Practice \& } \\
\text { Decent Work }\end{array}$ & 10 & $\begin{array}{l}\text { Employment, Labor/Management Relations, Occupational } \\
\text { Health\&Safety, Training\&Education, Diversity\& Equal } \\
\text { Opportunity }\end{array}$ \\
\hline & Human Rights & 10 & $\begin{array}{l}\text { Investment\&Procurement Practices, Non-Discrimination, } \\
\text { Freedom of Association and Collective Bargaining, Child } \\
\text { Labor, Forced\&Compulsory Labor, Security Practices, } \\
\text { Indigenous Rights }\end{array}$ \\
\hline & Society & 10 & $\begin{array}{l}\text { Community, Corruption, Public Policy, Anti-Competitive } \\
\text { Behavior, Compliance }\end{array}$ \\
\hline $\begin{array}{l}\cdot \pi \\
0 \\
\mathscr{n}\end{array}$ & $\begin{array}{l}\text { Product } \\
\text { Responsibility }\end{array}$ & 10 & $\begin{array}{l}\text { Product\&Service Labeling, Marketing Communications, } \\
\text { Compliance }\end{array}$ \\
\hline
\end{tabular}

1 Birleşik Fon Bankası is excluded from the analysis, since it is operating under the review of Savings Deposit and Insurance Fund. 
The CSR score for the ith bank is calculated by summing up each of the scores the bank possesses in each of the three dimensions:

$$
\text { Score }_{C S R}=\sum_{i=1}^{n} S_{\text {core }}\left(\text { Economic }_{i}, \text { Environmental }_{i}, \text { Social }_{i}\right)
$$

The score for the social dimension for the ith bank is similarly found by summing up scores in each of the four sub-dimensions:

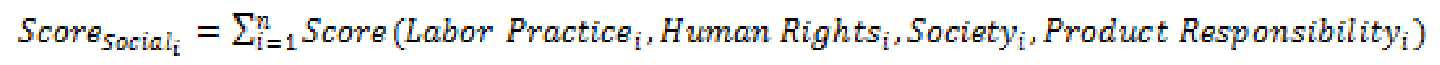

For each dimension and sub-dimension, further items were evaluated in the content analysis and these items are presented in Appendix. (For a detailed explanation about each item in appendix, see GRI's G4 Sustainability Reporting Guidelines, Reporting Principles and Standard Disclosures, n.d.:43-80).

After calculating the CSR scores for each bank, the paper further investigates the relationship between the CSR score and the financial performance indicators. Most of the empirical papers that are analyzing the financial performance of banks consider return on assets (ROA), return on equity (ROE) and net interest margins (NIMS). ROA and ROE are the most commonly used measures for bank performance (see for example, Micco etal., 2007; Demirgüç-Kunt, Huizinga, 2011; Naceur and Goaied, 2001 and for Turkey Taşkın, 2011; Doğan,2013; Demirel etal., 2013). NIM is also important in the way that it conveys significant information about the performance, profitability and stability of the financial system (Saunders and Schumacher, 2000: 814). ROA is the ratio of net profit over total assets, ROE is the ratio of net profit over total shareholders' equity and NIM is the ratio of net interest income to total assets. Two regressions are run to understand the two-way relationship between CSR and performance:

$$
\begin{aligned}
& \operatorname{Perf}_{i}=\alpha_{i}+\beta_{i} \operatorname{CSR}_{i}+\gamma_{i} \text { Size }_{i}+\varepsilon_{i} \\
& \operatorname{CSR}_{i}=\delta_{i}+\theta_{i} \operatorname{Perf}_{i}+\rho_{i} \text { Size }_{i}+\varepsilon_{i}
\end{aligned}
$$

For Equation 3, Perfi represents the ROA, ROE and NIM of the ith bank. Sizei represents the natural logarithm of the ith bank and is kept as a control variable in the regression. Equation 4 keeps the CSR score as the dependent variable and considers size and performance variables as explanatory variables in three separate regressions.

\section{Empirical Results}

Before presenting the results of the regression analysis, Table 3 displays average scores of the sample banks on the CSR practices they possess.

The summary scores show that on average the commercial private banks exhibit an average score of 30.24 on the aggregate CSR index. It is seen that on average, the banks are doing pretty good in terms of economic information disclosure. Despite the various projects the banks are undertaking about the environmental dimension, the average result turns out to be very low; 3.74. This is actually due to the tendency to support the projects to increase the size of the forestry areas and use of natural energy resources; whereas projects on biodiversity and water scarcity are mostly ignored. Among the social dimension, scores on society and human rights stand as very low. It can be concluded that, the sub-dimensions of these practices are still not considered as critical yet; hence banks fail to disclose any information about those practices so far. 
Taşkın, D. / Journal of Yasar University, 2015, Special Issue, 21-30

Table 3. Summary Information on the CSR Scores of Sample Banks

\begin{tabular}{|l|l|l|}
\hline CSR Information & 7.15 \\
\hline Economic & 3.74 & 6.09 \\
\hline Environmental & Labor Practice and Decent Work & 2.77 \\
\cline { 2 - 3 } Social & Human Rights & 4.44 \\
\cline { 2 - 3 } & Society & 6.06 \\
\cline { 2 - 3 } & Product Responsibility \\
\cline { 2 - 3 } & SubSum=19.35 \\
\hline Aggregate CSR-Index & 30.24 & \\
\hline
\end{tabular}

The results of the regression analysis for Equation 3 are displayed below:

Table 4: CSR as a Determinant of Performance

\begin{tabular}{|c|c|c|c|c|c|c|}
\hline Dep. Var. & ROA & & ROE & & NIM & \\
\hline Independent Var & Coeff. & Std. Er. & Coeff. & Std. Er. & Coeff. & Std. Er. \\
\hline CSR-Index & -0.0142 & 0.0095 & -0.0132 & 0.0607 & $0.1194 * *$ & 0.0431 \\
\hline Size & $0.3472 * * *$ & 0.0384 & $2.0944 * * *$ & 0.3776 & $\begin{array}{l}- \\
0.9229 * *\end{array}$ & 0.3391 \\
\hline Constant & $-1.8967 * * *$ & 0.2328 & $-10.400 * *$ & 3.1369 & $7.1945^{* *}$ & 2.5213 \\
\hline R-squared & \multicolumn{2}{|l|}{0.8598} & \multicolumn{2}{|l|}{0.8551} & \multicolumn{2}{|l|}{0.5838} \\
\hline Adj. R-squared & \multicolumn{2}{|l|}{0.8248} & \multicolumn{2}{|l|}{0.8189} & \multicolumn{2}{|l|}{0.4797} \\
\hline F-statistic & \multicolumn{2}{|l|}{$24.548 * * *$} & \multicolumn{2}{|l|}{$23.613 * * *$} & \multicolumn{2}{|l|}{$5.6109 * *$} \\
\hline
\end{tabular}

According to the results of the analysis, CSR scores were found decrease ROA and ROE, but with no statistical significance. But yet, we can say that banks with more CSR practices have lower profitability. On the other hand, CSR-index has a positive and significant coefficient, suggesting that banks with higher CSR scores tend to charge higher NIMs from their customers. This is a striking finding, which can be concluded that the banks with more CSR practices or disclosures are more costly to the customers. This can be voluntary, meaning that customers are more likely to prefer banks with more CSR practices even if they charge more. This can also be interpreted as the CSR costs of the banks are shared between the bank and its' customers, pointing to the fact that these costs are spread to the society as a whole. Size, on the other hand, is found to have a positive and significant effect on the ROA and ROE but a negative effect on the NIMS. The F-tests also denotes that the overall fit of the model is good at $1 \%$ significance level. 
Taşkın, D. / Journal of Yasar University, 2015, Special Issue, 21-30

Table 5. The Determinants of CSR

\begin{tabular}{|l|l|l|l|l|l|l|}
\hline Dependent Variable & \multicolumn{7}{|c|}{ CSR-Index } \\
\hline Independent Var & Coeff. & Std. Er. & Coeff. & Std. Er. & Coeff. & Std. Er. \\
\hline ROA & -10.477 & 8.1910 & - & - & - & - \\
\hline ROE & - & - & -0.2093 & 1.0358 & - & - \\
\hline NIM & - & - & - & - & $3.8204 * *$ & 1.3624 \\
\hline Size & $7.8967 * * *$ & 2.1590 & 5.4314 & 3.0997 & $6.2470^{* * *}$ & 0.9347 \\
\hline Constant & $-35.230^{*}$ & 16.029 & -20.185 & 23.025 & $-37.301 * * *$ & 12.496 \\
\hline R-squared & 0.7403 & 0.6955 & 0.8340 & \\
\hline Adjusted R-squared & 0.6754 & 0.6194 & 0.7926 & \\
\hline F-statistic & $11.407^{* * *}$ & $9.1403^{* * *}$ & $0.0007^{* * *}$ & \\
\hline
\end{tabular}

The results for the regression analyses that are based on Equation 4 are presented on Table 5 . The regressions show that ROA and ROE have negative coefficients with no significance. But still if we are to interpret these, the banks with higher profitability have a tendency to display lower CSR scores. But the banks with higher NIMs are more inclined to CSR practices with a statistical significance at 5\% level. The size variable also shows in the first and third regression that, as the asset size increases, the tendency to display more CSR practices will increase.

\section{Conclusion}

The Turkish banking system started to liberalize following the liberalization attempts in 1980s in many countries in the world. But since no proper and timely regulations were put into action, the banking system witnessed major crises. Especially in 1994 and 2001, many banks went bankrupt due to asset and liability mismatch. Undeniably, these court of events were not only because of the banking system itself, but also from the deterioration in the macroeconomic variables and also from the downturn of the global economy (i.e. crisis like Asian crisis, Russian crisis).

When we look at the activities of the banks before 2000s, it is seen that the banks did not perform their traditional banking activities like collecting deposits and giving loans. Rather, they enjoyed the incredibly high interest rates offered by the treasury bonds because of the high public sector borrowing requirements. So, we can say that, the banks did not fund the firms and individuals and they did not face any competition in the deposit and loan market. After the 2001 crisis, there was a recovery in the economic system and the interest rates declined to one digit levels. The interest rates offered by the government were very minimal compared to the past, thus banks were forced to perform their traditional banking activities. Also with the economic recovery, many foreign banks entered the market through mergers and acquisitions and there has been a visible consolidation in the market. These developments increased the competition in the market and pushed the markets to perform corporate social responsibility activities. Recently, many banks engage in social project to enhance the welfare of the society, by increasing the forest planted areas, aiding projects about energy, education and arts.

The paper attempts to analyze the impact of these CSR practices on the financial performance of the private national banks in Turkey for the year 2013. On the contrary, the impact of the financial performance measures on CSR practices is also analyzed. The financial performance measures adopted are ROA, ROE and NIM. Since these activities are increasing through time, these relations are crucial to investigate. In order to assign a CSR score for each bank, this paper uses content analysis. Based on the Global Reporting Initiatives Guidelines, each bank is given a score based on their disclosures about economic, social and environmental impacts. For this reason, the web sites, annual reports and sustainability reports were reviewed based on the items for each dimension. Any bank who disclosed the necessary information about the items in each dimension would receive a score of 60 . The financial performance measures for each bank were calculated 
using the financial statements of the banks. Further regressions are run to understand the bidirectional relationship between CSR and performance.

The results of the regressions show that the banks with higher CSR scores tend to have lower ROA and ROE, but the result is not statistically significant. Another striking fact is as the banks' scores increase, the amount of net interest margin they charge from their customers increase significantly, too. Conversely, the banks that have higher NIMs, have higher CSR scores, which shows a bidirectional relationship between NIM and CSR. On the other hand, the profitability measures, namely ROA and ROE, fail to explain the CSR scores. We cannot infer a statistically significant relation between those measures and CSR. Moreover banks with larger asset bases tend to be more profitable and are better in terms of CSR scores.

The results generally convey that the banks do not perform CSR only because they are profitable, also CSR practices do not guarantee profitability. The findings are in line with the Carroll's construct (1991) which states that the aim is not profit maximization, but rather meeting society's expectations. The higher amount of NIMs charged is a sign of the distribution of the costs of the CSR practices to the customers also. The banks do not only pay for the CSR, but also their customers take a role in the practices by making transactions in the aforementioned banks. This finding should be analyzed further. Obviously, every member in the society wants the projects that will enhance the social, economic and environmental issues to be promoted, but the answer to the question of who is paying for those projects seems ambiguous. The regulatory bodies should promote the presence of the companies in CSR practices, but the control for the spread of the cost should be increased. 
Taşkın, D. / Journal of Yasar University, 2015, Special Issue, 21-30

\section{REFERENCES}

Ararat, M. (2008). A Development Perspective for Corporate Social Responsibility: Case of Turkey. Corporate Governance: The International Journal of Business in Society, 8(3), 271- 285.

Belkaoui, A. (1976). The Impact of the Disclosures of the Environmental Effects of Organizational Behaviour on the Market, Journal of Financial Management, 5, 56-31.

Bragdon, J.H. and J. Marlin. 1972. Is pollution profitable? Journal of Risk Management. 19(4)., 918

Carroll, A.B. (1999). Corporate Social Responsibility- Evolution of a Definitional Construct. Business and Society, 38(3), 268-295.

Demirel, E., Atakişi, A. and Abacıoğlu, S. (2013). Bankacılık Faaliyet Oranlarının Panel Veri Analizi: Türkiye'deki Kamu, Özel ve Yabancı Sermayeli Bankaların Durumu. Muhasebe ve Finansman Dergisi, 59, 101-112.

Demirgüç-Kunt, A. and Huizinga, H. (2011). Do We Need Big Banks? Evidence on Performance, Strategy and Market Discipline. European Banking Center Discussion Paper, No:2011005.

Doğan, M. (2013). Measuring Bank Performance with Gray Relational Analysis: The Case of Turkey. Ege Academic Review, 13(2), 215-225.

Frooman, J. (1997). Socially Irresponsible and Illegal Behavior and Shareholder Wealth A MetaAnalysis of Event Studies. Business and Society 36 (3), 221-249.

Global Reporting Initiative. G4 Sustainability Reporting Guideliness: Reporting Principles and Standard Disclosures. https://www.globalreporting.org/resourcelibrary/GRIG4-Part1Reporting-Principles-and-Standard-Disclosures.pdf Access Date: 03.06.2014.

McGuire, J.; Sundgren, A. and Schneeweis, T. (1988). Corporate Social Responsibility and Firm Financial Performance. Academy of Management Journal, 31(4), 854-872.

McWilliams, A. and Siegel, D. (2001). Corporate Social Responsibility: A Theory of the Firm Perspective. Academy of Management Review, 26, 117-127.

Micco, A., Panizza,U. and Yanez, M. (2007). Bank Ownership and Performance. Does Politics Matter? Journal of Banking and Finance, 31, 219-241.

Naceur, S.B. and Goaied, M. (2001). The Determinants of the Tunasian Deposit Banks' Performance. Applied Financial Economics, 11, 317-319.

Nuhoğlu, N.I. and Wan, L. (2012). Corporate Social Responsibility Disclosure in Two Rising Actors: China and Turkey. MÖDAV, Muhasebe Bilim Dünyası Dergisi, 14(1), 67-86.

Preston, L. E. and O'Bannon, D. P. (1997). The Corporate Social-Financial Performance Relationship: A Typology and Analysis. Business and Society, 36, 419-429.

Saunders, A. and Schumacher, L. (2001). The Determinants of Bank Interest Rate Margins: An International Study. Journal of International Money and Finance, 19, 813-832.

Stanwick, P. A. and Stanwick, S.D. (1998). The Relationship between Corporate Social Performance, and Organizational Size, Financial Performance, and Environmental Performance: An Empirical Examination, Journal of Business Ethics, 17 (2), 195-204.

Taskin, F.D. (2011). Türkiye'de Ticari Bankaların Performansını Etkileyen Faktörler. Ege Akademik Bakış, 11(2), 289-298.

Turker, D. (2009). Measuring Corporate Social Responsibility: A Scale Development Study. Journal of Business Ethics, 85, 411-427.

Ullman, A.A. (1985). Data in Search of a Theory: A Critical Examination of the Relationship among Social Performance, Social Disclosure and Economic Performance of U.S. Firms. Academy of Management Review, 10(3), 540-557.

Waddock, S. A. and Graves, S. B. (1997). The Corporate Social Performance- Financial Performance Link. Strategic Management Journal, 18, 303-319. 
Taşkın, D. / Journal of Yasar University, 2015, Special Issue, 21-30

Zengin Karaibrahimoglu, Y. (2010). Corporate Social Responsibility in Times of Financial Crisis. African Journal of Business Management, 4(4), 382-389.

\begin{tabular}{|c|c|c|}
\hline \multicolumn{3}{|c|}{ CSR Information } \\
\hline \multirow{4}{*}{ Economic } & Economic Performance & \\
\hline & Market Presence & \\
\hline & Indirect Economic Impacts & \\
\hline & Average & \\
\hline \multirow[t]{9}{*}{ Environmental } & Materials & \\
\hline & Energy & \\
\hline & Water & \\
\hline & Biodiversity & \\
\hline & Emissions Effluents Waste & \\
\hline & Products Services & \\
\hline & Compliance & \\
\hline & Transport & \\
\hline & Overall & \\
\hline \multirow[t]{24}{*}{ Social } & Labor Practice and Decent Work & Employment \\
\hline & & Labor Management \\
\hline & & Occupational Health Safety \\
\hline & & Training and Education \\
\hline & & Diversity Equal Opportunity \\
\hline & & Average \\
\hline & Human Rights & Investment Procurement Practices \\
\hline & & Non-Discrimination \\
\hline & & $\begin{array}{l}\text { Freedom of Association and } \\
\text { Collective Bargaining }\end{array}$ \\
\hline & & Child Labor \\
\hline & & Forced and Compulsory Labor \\
\hline & & Security Practices \\
\hline & & Indigenous Rights \\
\hline & & Average \\
\hline & Society & Community \\
\hline & & Corruption \\
\hline & & Public Policy \\
\hline & & Anti-Competitive Behavior \\
\hline & & Compliance \\
\hline & & Average \\
\hline & Product Responsibility & Product and Service Labeling \\
\hline & & Marketing Communications \\
\hline & & Compliance \\
\hline & & Average \\
\hline
\end{tabular}

